\title{
Colonial Waterbirds Nesting on Egg Island, Lake Athabasca, 2009
}

\author{
Craig Hebert ${ }^{1}$, WAYNe Nordstrom ${ }^{2}$, and LAird ShutT ${ }^{1}$ \\ ${ }^{1}$ Environment Canada, Wildlife and Landscape Science Directorate, National Wildlife Research Centre, 1125 Colonel By \\ Drive, Ottawa, Ontario K1A 0H3 Canada \\ ${ }^{2}$ Alberta Parks, Parks Ecology Program, 3rd floor, Oxbridge Place, 9820 - 106 Street, Edmonton, Alberta T5K 2J6 Canada
}

Hebert, Craig, Wayne Nordstrom, and Laird Shutt. 2010. Colonial waterbirds nesting on Egg Island, Lake Athabasca, 2009. Canadian Field-Naturalist 124(1): 49-53.

In June 2009 a census was conducted of colonial waterbirds breeding on Egg Island in western Lake Athabasca. This island supports the largest breeding colony of Caspian Terns (Hydroprogne caspia) in Alberta. California Gulls (Larus californicus) and Herring Gulls (Larus argentatus) also nest on the island. One hundred and one Caspian Tern nests (=pairs) were counted during 2009. Since 1990, the number of terns nesting on the island appears stable. However, more frequent surveys of waterbird populations are recommended, particularly in light of growing industrial activity in this region.

Key Words: Caspian Tern, Hydroprogne caspia, California Gull, Larus californicus, Herring Gull, Larus argentatus, Egg Island, Lake Athabasca, Alberta.

Egg Island $\left(58.981^{\circ} \mathrm{N},-110.439^{\circ} \mathrm{W}\right)$ in western Lake Athabasca (Figure 1) supports the largest Caspian Tern (Hydroprogne caspia) colony in the province of Alberta (http://tpr.alberta.ca/parks/managing/sitedesc_can shield.asp). In recognition of this fact, the island was designated an ecological reserve by the province in 1992. It is the smallest ( 0.36 ha) such reserve in Alberta. Egg Island is approximately $70 \mathrm{~m}$ long by $40 \mathrm{~m}$ wide, is elliptical in shape, and has a surface of pebble, cobble, and boulder gravel. It rises to a maximum elevation of approximately $2.5 \mathrm{~m}$ above lake level. The island also supports breeding populations of California Gulls (Larus californicus) and Herring Gulls (Larus argentatus). Terns have likely nested in this area since at least the early 1900s. Sightings of Caspian Terns in the vicinity of Egg Island date back to 1903. Caspian Terns were observed in the Lake Athabasca Delta in June 1903 (Preble 1908) and 1907 (Seton 1911). Soper (1942) made additional sightings in the Delta in late May and late June in 1932 and 1933, respectively. The earliest census of Caspian Terns nesting on Egg Island was completed in 1952 with approximately 20 breeding pairs reported (Salt and Wilk 1958, 1966; Salt and Salt 1976). Surveys were conducted intermittently in subsequent years. In early July 1971, Hohn (1973) visited Egg Island and estimated there were approximately 20 pairs of Caspian Terns and 50-80 pairs of California Gulls nesting on the island. Weseloh and Cocks (1979) censused the island again in June, 1977 and counted 47 Caspian Tern nests along with one Herring Gull nest. They estimated a maximum of 100 pairs of California Gulls nesting on the island. Weseloh and Cocks (1979) provide an excellent summary of the early Caspian Tern accounts for this region. In more recent years, Nordstrom and coworkers visited the island on two occasions. On 12 July 1990, Nordstrom (unpublished data) estimated approximately 150-200 adult Caspian Terns were breeding on the island. Data for other species were not collected. On 11 June 2001, Nordstrom, Vujnovic and Thomas (unpublished data) reported at least 150 pairs of nesting Caspian Terns. They also estimated that there were about 400 adult California Gulls, about 10 adult Herring Gulls, about 60 adult Ringbilled Gulls and about 30 adult Common Terns on/ around the island. However, there are no records of the latter two species nesting on the island.

Parts of northern Alberta have seen a significant increase in industrial activity over the past two decades. This is evident in the Fort McMurray area where the Oil Sands are under development (National Energy Board 2004*, Alberta Environment 2008*). A major river, the Athabasca River, flows through Fort McMurray and the area where many of the Oil Sands operations are underway. The river flows northwards into western Lake Athabasca approximately $200 \mathrm{~km}$ downstream from Fort McMurray, the industrial hub of Oil Sands development (see Figure 1). The intention of our research was to provide updated information regarding the size of the populations of colonial waterbirds that breed on Egg Island. These data will be used to assess future trends in waterbird populations as a result of environmental change.

\section{Methods}

On 14 June 2009, we visited Egg Island via floatplane (Figure 2). Snow and ice drifts were still present in waters adjacent to some parts of the island but, overall, the waters of Lake Athabasca were ice-free. We arrived on the island at 08:00 (Mountain Standard Time, UTC-7) and spent approximately 1 hour counting nests, taking egg measurements for California Gulls, and collecting Caspian Tern and California Gull eggs for toxicological and dietary analysis. Here, we report population, clutch size distribution, and egg size data. Egg volume was estimated using the equation: 


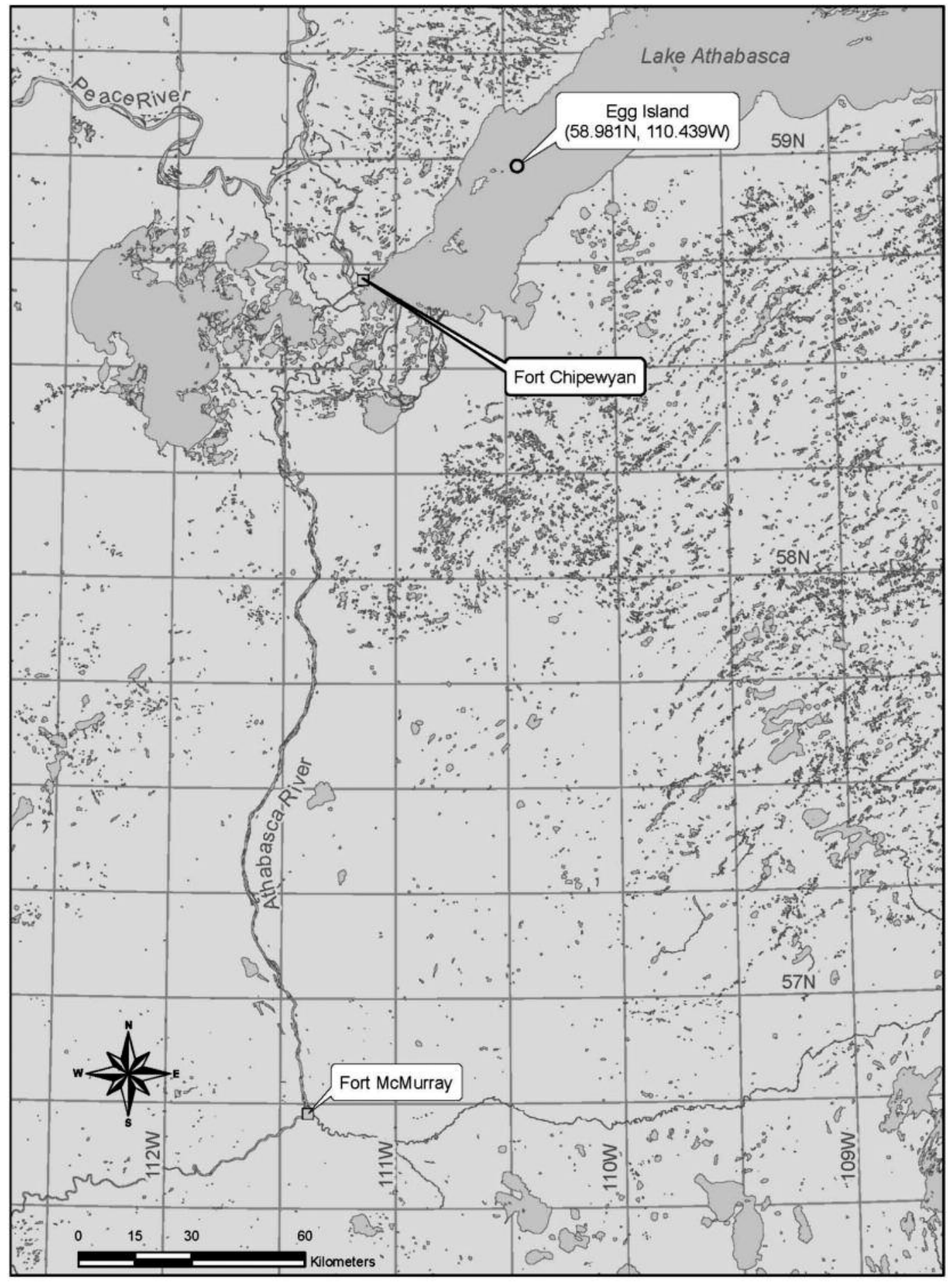

Figure 1. Map of the study region. 


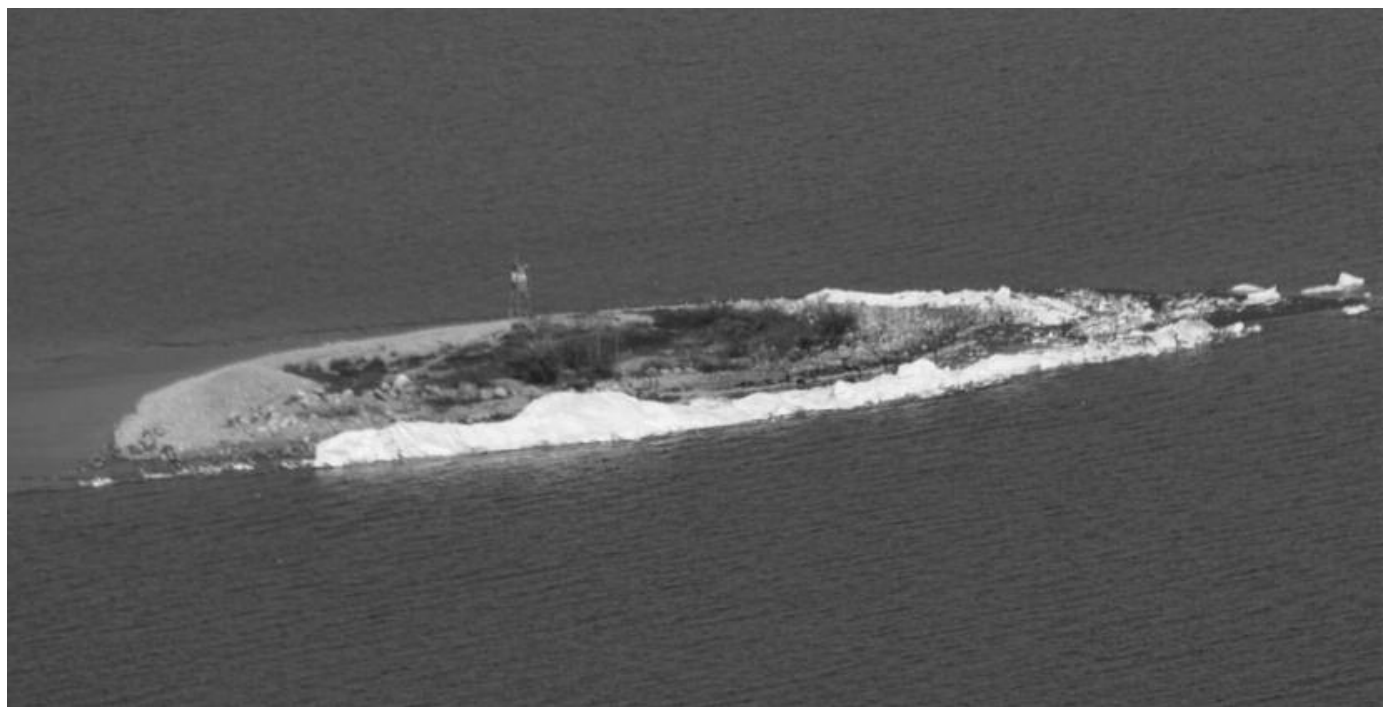

FIGURE 2. Aerial view of Egg Island, Lake Athabasca, 14 June 2009.

Volume $\left(\mathrm{cm}^{3}\right)=0.489\left(\right.$ length $\times$ breadth $\left.^{2}\right) / 1000$ (Ryder 1975)

Two biologists surveyed the entire island and counted nests for each of three species: Caspian Terns, California Gulls, and Herring Gulls. For California Gulls, egg measurements (length and breadth) were obtained from completed 3-egg clutches. Similar data are not reported for the other two species because there were no 3-egg clutches for Caspian Terns and there were few Herring Gull nests.

\section{Results}

Caspian Terns were the most abundant species breeding on the island with 101 nests counted (Figure 3).
TABLE 1. Clutch size distribution data for waterbird species nesting on Egg Island, 14 June, 2009.

\begin{tabular}{lrrrrr}
\hline \hline Species & \multicolumn{3}{c}{ Clutch Size } & & Total \\
\hline & 0 & 1 & 2 & 3 & \\
Caspian Tern & 29 & 31 & 41 & 0 & 101 \\
California Gull & 14 & 29 & 22 & 22 & 87 \\
Herring Gull & 0 & 0 & 1 & 2 & 3 \\
\hline \hline
\end{tabular}

In addition, there were 87 California Gull nests and 3 Herring Gull nests. Clutch size distribution data were also collected and are shown in Table 1. Average clutch size for Caspian Terns breeding in northern North America is three eggs (Bent 1921). Similarly, modal

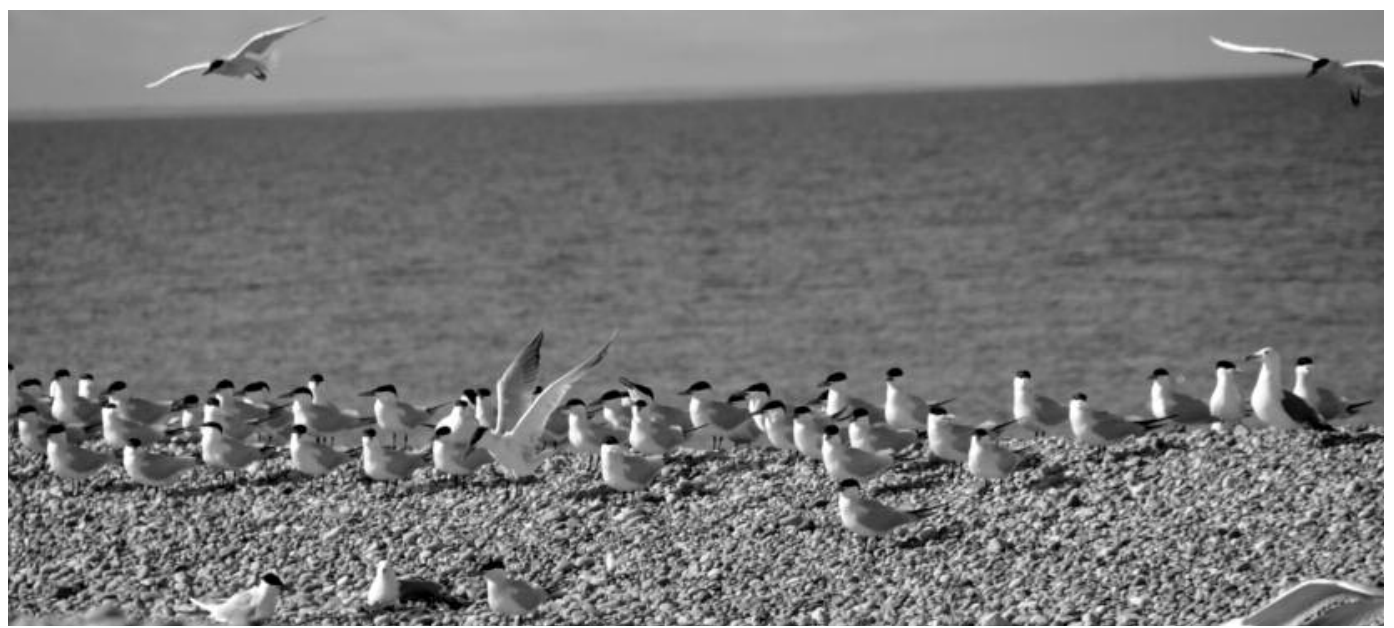

Figure 3. Approximately one-third of the Caspian Terns breeding on Egg Island, Lake Athabasca, 14 June 2009. 
clutch size for California Gulls nesting at another Alberta colony was three eggs (Vermeer 1970). Herring Gulls have also been reported to have a modal clutch size of three eggs (Tinbergen 1960). Clutch size distribution data indicated that egg-laying was still occurring for all species with the gulls somewhat more advanced than the terns. Mean ( \pm standard deviation) egg size data from 3-egg clutches of California Gulls were as follows: length $64.59 \pm 2.33 \mathrm{~mm}$, breadth $45.73 \pm 1.33 \mathrm{~mm}$, volume $66.14 \pm 4.99 \mathrm{~cm}^{3}$. Mean clutch volume was $198.43 \pm 11.00 \mathrm{~cm}^{3}$. Mean percent difference between the largest and smallest egg within a clutch (intra-clutch variation in egg size) was $9.76 \pm 6.20 \%$. With respect to the collection of fresh eggs, the timing of the visit on 14 June was nearly optimal as eggs from all species were available but there were no complete three-egg clutches for Caspian Terns. Future visits (assuming similar weather conditions) could be delayed for several days to ensure the presence of complete clutches for all species.

\section{Discussion}

The nest count data reported here are consistent with census information from 1990 and 2001. Although the level of accuracy of the counts varied during the last three surveys, they indicated that the number of Caspian Terns breeding on the island reached its peak during the past two decades and has been stable at 100200 pairs. This trend combined with forthcoming information regarding contaminant levels in the 2009 eggs will provide a benchmark against which to evaluate future change. In light of growing economic development in this region, more frequent censuses of waterbird populations on Egg Island are recommended. Waterbirds, such as terns and gulls, are useful indicators of environmental quality and ecosystem change (Kushlan 1993; Hebert et al. 1999, 2008). Egg size data for California Gulls were similar to those reported previously for that species in Alberta (Vermeer 1969). However, mean clutch volumes and intra-clutch differences in egg size showed substantial variation among clutches. Such endpoints can be valuable in assessing food stress and their long-term monitoring can provide insights into how ecosystem change may alter food availability for top predators (Hebert et al. 2002, 2009). Regular monitoring of waterbird populations would be a useful addition to programs assessing the potential environmental impacts of Oil Sands development (e.g., Regional Aquatics Monitoring Program, see Golder Associates 2003*) and for assessing ecological change in general.

\section{Acknowledgments}

The authors thank Fish and Wildlife Division of Alberta Sustainable Resource Development and Alberta Tourism, Parks, and Recreation for granting permits allowing this work to take place. Permits were also obtained from the Canadian Wildlife Service. Seth
Melmock of McMurray Aviation provided transportation to the island. Jeannine Paquette produced Figure 1. A. J. Erskine and C. Stuart Houston provided comments that improved the manuscript. Environment Canada's Ecotoxicology and Wildlife Health Program supported this research.

\section{Documents Cited (marked * in text)}

Alberta Environment. 2008. Alberta's Oil Sands: Opportunity, Balance. http://www.environment.alberta.ca/docu ments/Oil_Sands_Opportunity_Balance.pdf Government of Alberta, Edmonton, Alberta.

Golder Associates. 2003. Oil Sands Regional Aquatics Monitoring Program (RAMP) five-year report. May 2003. http://www.ramp-alberta.org/UserFiles/File/Supporting/ RAMP\%20Five\%20Year\%20Report.pdf. Prepared for the RAMP Steering Committee. Calgary, Alberta.

National Energy Board. 2004. Canada's Oil Sands: Opportunities and Challenges to 2015. http://www.neb.gc.ca/clfnsi/rnrgynfmtn/nrgyrprt/lsnd/lsnd-eng.html. Government of Canada, National Energy Board, Calgary, Alberta.

\section{Literature Cited}

Bent, A. C. 1921. Life histories of North American gulls and terns. U.S. National Museum Bulletin 113.

Hebert, C. E., R. J. Norstrom, and D. V. Weseloh. 1999. A quarter century of environmental surveillance: the Canadian Wildlife Service's Great Lakes Herring Gull Monitoring Program. Environmental Reviews 7: 147-166.

Hebert, C. E., J. L. Shutt, and R. O. Ball. 2002. Plasma amino acid concentrations as an indicator of protein availability to breeding Herring Gulls (Larus argentatus). Auk 119: 185-200.

Hebert, C. E., D. V. C. Weseloh, A. Idrissi, M. T. Arts, R. O'Gorman, O. T. Gorman, B. Locke, C. P. Madenjian, and E. F. Roseman. 2008. Restoring piscivorous fish populations in the Laurentian Great Lakes causes seabird dietary change. Ecology 89: 891-897.

Hebert, C. E., D. V. C. Weseloh, A. Idrissi, M. T. Arts, and E. F. Roseman. 2009. Diets of aquatic birds reflect changes in the Lake Huron ecosystem. Aquatic Ecosystem Health and Management 12: 37-44.

Hohn, E. O. 1973. The birds of the Peace-Athabasca Delta and of the Lake Athabasca region. Canadian Wildlife Service. 32 pages.

Kushlan, J. A. 1993. Colonial waterbirds as biodindicators of environmental change. Colonial Waterbirds 16: 223-251.

Preble, E. A. 1908. A biological investigation of the Athabasca -Mackenzie region. North American Fauna 27. 574 pages.

Ryder, J. P. 1975. Egg-laying, egg-size and success in relation to immature-mature plumage of Ring-billed Gulls. Wilson Bulletin 87: 534-542.

Salt, W. R., and J. R. Salt. 1976. The birds of Alberta with their ranges in Saskatchewan and Manitoba. Hurtig Publishers, Edmonton. 488 pages.

Salt, W. R., and A. L. Wilk. 1958. The birds of Alberta. Department of Economic Affairs, Edmonton. 511 pages.

Salt, W. R., and A. L. Wilk. 1966. The birds of Alberta. 2nd revised edition. Queen's Printer, Edmonton, Alberta. 512 pages.

Seton, E. T. 1911. The Arctic Prairies. C. Scribner \& Sons, New York. 415 pages.

Soper, J. D. 1942. The birds of Wood Buffalo Park and vicinity. Transactions Royal Canadian Institute 24: 19-97. 
Tinbergen, N. 1960. The Herring Gull's world. 2nd edition. Basic Books, New York.

Vermeer, K. 1969. Egg measurements of California and Ring-billed Gull eggs at Miquelon Lake, Alberta, in 1965. Wilson Bulletin 81: 102-103.

Vermeer, K. 1970. Breeding biology of California and Ringbilled Gulls: a study of ecological adaptation to the inland habitat. Canadian Wildlife Service Report Series Number 12.
Weseloh, D. V. C., and L. Cocks. 1979. Recent nesting of the Caspian Tern at Egg Island, Lake Athabasca, Alberta. Blue Jay 37: 212-215.

Received 17 November 2009

Accepted 24 April 2010 